\title{
Production of Cold-Active Lipase by Free and Immobilized Marine Bacillus cereus HSS: Application in Wastewater Treatment
}

\section{OPEN ACCESS}

Edited by:

Pankaj Kumar Arora, Babasaheb Bhimrao Ambedkar

University, India

Reviewed by:

M. Oves,

King Abdulaziz University,

Saudi Arabia

Kumari Kavita,

National Institutes of Health (N/H),

United States

${ }^{*}$ Correspondence:

Sahar W. M. Hassan saharwefky@yahoo.com

Specialty section:

This article was submitted to Microbiotechnology, Ecotoxicology

and Bioremediation,

a section of the journal

Frontiers in Microbiology

Received: 05 July 2018 Accepted: 18 September 2018 Published: 23 October 2018

Citation: Hassan SWM, Abd El Latif HH and Ali SM (2018) Production

of Cold-Active Lipase by Free and Immobilized Marine Bacillus

cereus HSS: Application

in Wastewater Treatment.

Front. Microbiol. 9:2377.

doi: $10.3389 /$ fmicb.2018.02377

\author{
Sahar W. M. Hassan ${ }^{1 *}$, Hala H. Abd El Latif ${ }^{2}$ and Safaa M. Ali² \\ ${ }^{1}$ National Institute of Oceanography and Fisheries, Alexandria, Egypt, ${ }^{2}$ City of Scientific Research and Technological \\ Applications, Alexandria, Egypt
}

Lipases are enzymes that have the potential to hydrolyze triacylglycerol to free fatty acids and glycerol and have various applications. The aim of the present study was to isolate and screen marine bacteria for lipase production, optimize the production, and treat wastewater. A total of 20 marine bacterial isolates were obtained from the Mediterranean Sea and were screened for lipase production. All isolates were found to have lipolytic ability. The differences between the isolates were studied using RAPDPCR. The most promising lipase producer (isolate 3) that exhibited the highest lipolytic hydrolysis $(20 \mathrm{~mm}$ ) was identified as Bacillus cereus HSS using 16S rDNA analysis and had the accession number MF581790. Optimization of lipase production was carried out using the Plackett-Burman experimental design with cotton seed oil as the inducer under shaking conditions at $10^{\circ} \mathrm{C}$. The most significant factors that affected lipase production were $\mathrm{FeSO}_{4}, \mathrm{KCl}$, and oil concentrations. By using the optimized culture conditions, the lipase activity increased by 1.8-fold compared with basal conditions. Immobilization by adsorption of cells on sponge and recycling raised lipase activity by 2.8-fold compared with free cells. The repeated reuse of the immobilized $B$. cereus HSS maintained reasonable lipase activity. A trial for the economic treatment of oily wastewater was carried out. Removal efficiencies of biological oxygen demand, total suspended solids, and oil and grease were 87.63, 90, and 94.7\%, respectively, which is promising for future applications.

Keywords: lipase, Plackett-Burman, immobilization, recycling, wastewater treatment

\section{INTRODUCTION}

Lipases (triacylglycerol acylhydrolase, EC 3.1.1.3) catalyze the hydrolysis and synthesis of longchain acylglycerols (Salihu and Alam, 2012; Lajis, 2018). They also catalyze the hydrolysis of triglycerides and reverse reactions (interesterification and esterification) (Saxena et al., 2003) and are involved in aminolysis, acidolysis, and alcoholysis. Lipases are produced by archaea, bacteria, fungi, animals, and plants (Cai-hong et al., 2008). Animal and plant lipases are less stable than those of microbial origin. The production of microbial lipases is more suitable, economic, and safer (Vakhlu and Kour, 2006; Treichel et al., 2010). Lipolytic enzymes secreted by Bacillus spp. are of considerable biotechnological importance. B. alcalophilus, B. licheniformis, B. pumilus, and B. subtilis are the common bacterial lipase producers (Lindsay et al., 2000; Awad et al., 2015). 
The production of biodiesel and biopolymers using lipases has been successfully recognized as a novel biotechnological application; furthermore, they can be used in the assembly of new pharmaceuticals, agrochemicals, and flavor compounds in addition to their various industrial applications (Hasan et al., 2006; Chary and Devi, 2018; Sarmah et al., 2018).

Cold-adapted enzymes are considered as biocatalysts for industrial applications. They are used in the synthesis of fine chemicals, food additives, detergents, and in the bioremediation of contaminated water and soil (Margesin and Feller, 2010; Cavicchioli et al., 2011; Patel and Desai, 2018). The manufacture of lipases with cold-active properties is generally extracellular and is greatly affected by nutritional and physicochemical factors, including inducers, nitrogen source, carbon source, temperature, agitation, $\mathrm{pH}$, inorganic sources, and dissolved oxygen (Joshi et al., 2006; Ephraim et al., 2014). It was stated that Bacillus spp. could easily use different nutrient sources. However, there were limited searches for the development of a suitable medium supplemented with natural nutrient sources such as vegetable oils for higher lipolytic capability (Ephraim et al., 2014). Optimization of lipase production was performed in many studies (Park et al., 2013; Anasontzis et al., 2014; Bharathi et al., 2018; Sahoo et al., 2018).

For long term enzyme activity, immobilization meets this requirement. Immobilization proposes several advantages such as recycle, ease in applications, stability, improved control of reactions, and simple removal of the immobilized object from the medium (Betigeri and Neau, 2002). Methods of immobilization can be divided into three categories: encapsulation, noncovalent attachment to a support, or covalent and carrier-free cross-linking (Gabrielczyk et al., 2018).

Presence of oily wastes in the aquatic environment prevents the diffusion of oxygen into water, which causes the death of many aquatic organisms. Lipases and microbial strains represent green alternatives for wastewater treatment and can have an effect on reducing the oil and fat content in the wastewater; they may assist in controlling severe pollution problems caused by wastewater. Many previous studies have reported the use of lipolytic enzymes for wastewater treatment (Sarac and Ugur, 2015; Silva-Bedoya et al., 2016; Hu et al., 2018).

Thus, the main goal of the present study is screening for lipase production by diverse bacteria isolated from marine environment and optimization of production setting by statistical means and immobilization techniques. Furthermore, an experiment for wastewater management using the most promising lipase producer will be investigated.

\section{MATERIALS AND METHODS}

\section{Isolation and Primary Screening for Lipase Production by Different Bacterial Isolates}

Marine bacteria were isolated from different sites along the Mediterranean Sea, including Eastern Harbor, Al Shatby, and Abu-Qir, and were cultured on nutrient agar plates $(\mathrm{pH} \mathrm{7)}$ that were prepared with aged filtered seawater. Media used throughout this study were supplied from Oxoid LTD, England. All the chemicals used were of analytical reagent grade.

Lipolytic capability of the isolated bacteria was screened using modified Tween agar base plates that contained the following $\left(\mathrm{gl}^{-1}\right)$ : beef extract, 3 ; peptone, 5 ; (50\% seawater and 50\% distilled water). The medium was amended by $1 \%$ Tween $80(\mathrm{v} / \mathrm{v})$. The development of clearance zone (hydrolysis) was considered as a positive result. The size of the halo-forming zones was measured after $24 \mathrm{~h}$ of incubation.

\section{Secondary Quantitative Screening for Lipase Production by the Different Isolates}

Secondary screening was performed by the quantification of lipase activity (Kanwar et al., 2006). All isolates were inoculated in mineral based medium that was supplemented with $1 \%(\mathrm{v} / \mathrm{v})$ cotton seed oil and were incubated at $10^{\circ} \mathrm{C}$. Production of lipase was assayed for different time intervals (24, 48, and $72 \mathrm{~h}$ ). Production medium contained the following $\left(\mathrm{gl}^{-1}\right)$ : yeast extract, 0.5; sucrose, 0.5; $\mathrm{NaNO}_{3}, 0.03 ; \mathrm{K}_{2} \mathrm{HPO}_{4}, 0.01 ; \mathrm{MgSO}_{4}, 0.05$; $\mathrm{KCl}, 0.05$; and $\mathrm{FeSO}_{4} .7 \mathrm{H}_{2} \mathrm{O}, 0.001$, adjust $\mathrm{pH}$ to 7 . Subsequently, centrifugation at $10000 \times g$ for $20 \mathrm{~min}$ at $4^{\circ} \mathrm{C}$ was carried out to collect the cell free supernatant for lipase assay (Jensen, 1983).

\section{Lipase Assay}

Estimation of lipase activity was resolute by the titrimetric technique using cotton seed oil as a substrate (Jensen, 1983). In brief, cotton seed oil was emulsified with Arabic gum in $0.05 \mathrm{mM}$ Tris buffer ( $\mathrm{pH} 7$ ). A volume of $100 \mu \mathrm{l}$ of the enzyme was added to the emulsion and incubated at $10^{\circ} \mathrm{C}$ for $30 \mathrm{~min}$. The reaction was blocked by the addition of acetone: ethanol (1:1). The liberated fatty acids were predicted by titration with $0.05 \mathrm{M} \mathrm{NaOH}$ using phenolphthalein as an indicator. Lipase activity was articulated as the amount of enzyme essential to hydrolyze 1 mole of fatty acids from triglyceride per minute.

\section{DNA Isolation and Random Amplification of Polymorphic DNA (RAPD-PCR)}

Genomic DNA was extracted using the Thermo Fisher kit. Quantity and quality of DNA was determined by Nanodrop spectrophotometric method (Kirby, 1993). Quality of the DNA was checked by calculating the ratio between $\mathrm{OD}_{260}$ and $\mathrm{OD}_{280}$. RAPD-PCR was used to differentiate between the bacterial isolates to detect the dissimilarity between the isolates. Reaction mixture of RAPD-PCR contained the following: $50 \mathrm{ng}$ genomic DNA, $1 \mu$ l of $1 \mathrm{X}$ buffer, $0.2 \mathrm{mM}$ dNTPs, $1 \mu \mathrm{l}$ of 10 picomole primer, 2 units of Taq DNA polemerase, and RNAse and DNAse free water. RAPD is a multiplex marker system that predictably uses single primer to amplify random DNA fragments. Two general oligonucleotide primers were used for the amplification: 16S F: AGAGTTTGATCMTGGCTCAG, 16S1100R: GGG TTG CGC TCG TTG. PCR consists of the following three steps: denaturation at $94^{\circ} \mathrm{C}$ for $1 \mathrm{~min}$, annealing at $30^{\circ} \mathrm{C}$ for $1 \mathrm{~min}$, and extension at $72^{\circ} \mathrm{C}$ for $1 \mathrm{~min}$. After amplification by PCR, the 
products were checked in $2 \%$ agarose gel. Genetic miscellany was determined as the experimental number of differentiation.

\section{Molecular Identification of the Most Potent Isolate (HSS)}

DNA was isolated and purified using the standard procedure (Sambrook et al., 1989). The region of 16S rRNA was amplified using the universal primers (F: 5'AGAGTTTGATCMTGGCTCAG3'and R: 5'TACGGYACCTTGTTACGACTT3'). The reaction was performed using a template DNA. Sequences of the $16 \mathrm{~S}$ rRNA genes were obtained from the NCBI database. Multiple alignments based on the most closely related sequences and similarity levels were carried out using the BLAST program ${ }^{1}$. A phylogenetic tree was reconstructed using the Bioedit software.

\section{Effect of Temperature on Lipase Activity}

The effect of temperature on lipase production was determined by incubating the culture flasks at different temperature (10, 25 , and $30^{\circ} \mathrm{C}$ ). Lipase assay was performed separately for each experiment.

\section{Effect of Agitation and Different Inducers on Lipase Activity}

Two sets of flasks were used to study the effect of aeration; one was incubated under static conditions and the other was kept under shaking condition at $120 \mathrm{rpm}$. For investigating the effect of different substrates on lipase production, $1 \%(\mathrm{v} / \mathrm{v})$ of each sterilized oil, including coconut oil, olive oil, sesame oil, corn oil, and palm oil was added separately to the basal medium for $24 \mathrm{~h}$ at $10^{\circ} \mathrm{C}$. Lipase assay was performed separately for each experiment.

\section{Optimization of Culture Conditions for Lipase Production Using Plackett-Burman Experimental Design}

Screening for the virtual consequence of different factors on lipase production was performed by applying the PlackettBurman experimental design (Plackett and Burman, 1946; Yu et al., 2009). Low ( - ) and high (+) levels of each variable were tested as shown in Table 3. In this experiment, 11 independent variables were screened in 12 combinations that were organized according to the Plackett-Burman matrix (Table 3). Row no. 13 in Table 3 illustrates the control (basal). The following equation was used to estimate the main effect of each variable: $\mathrm{Exi}=(\mathrm{Mi}+-\mathrm{Mi}-) / \mathrm{N}$, where Exi is the variable main effect, $\mathrm{Mi}+$ and $\mathrm{Mi}$ - are the lipase activities $(\mathrm{U} / \mathrm{ml})$ in the trials where the independent variables were shown in low and high concentrations, respectively, and $\mathrm{N}$ is the number of trials divided by two. Microsoft Excel was applied to calculate the statistical $t$-values for equal unpaired samples and significance of each variable. Verification test was performed to confirm the validity of the optimized medium.

\footnotetext{
${ }^{1}$ http://www.ncbi.nlm.nih.gov/blast
}

\section{Effect of Immobilization on Lipase Production by $B$. cereus HSS Immobilization by Entrapment in Calcium Alginate Beads}

Entrapment was performed using 3\% sodium alginate as previously described (Eikmeier and Rhem, 1987). Sodium alginate $(0.75 \mathrm{~g})$ was dissolved in $23 \mathrm{ml}$ of distilled water, followed by autoclaving at $121^{\circ} \mathrm{C}$ for $10 \mathrm{~min}$. A volume of $2 \mathrm{ml}$ of $B$. cereus HSS suspension was added to the prepared sodium alginate solution. A volume of $10 \mathrm{ml}$ of the bacterial-alginate combination was drawn by using a sterilized syringe and was introduced into sterile $2 \% \mathrm{CaCl}_{2}$ solution, and the resultant calcium alginate beads entrapping the bacteria were left in $\mathrm{CaCl}_{2}$ solution for about $2 \mathrm{~h}$ to solidify. Later, the beads were washed several times with sterile distilled water and used as inoculum for $25 \mathrm{ml}$ of the optimized medium.

\section{Immobilization by Adsorption}

Bacterial immobilization by adsorption was carried out on different solid supports (luffa pulp, clay, ceramic, sponge, and pumice). Bacterial suspensions $(2 \mathrm{ml})$ were added to $25 \mathrm{ml}$ sterile flasks containing the optimized culture medium and $5 \mathrm{~g}$ of each porous support. Both sponge and luffa pulp were cut to pieces of the size $0.5 \mathrm{~cm}$ and were washed with water before use. The flasks were incubated under slow shaking condition at $120 \mathrm{rpm}$ for $24 \mathrm{~h}$. Lipase activity was estimated each time and was compared with the free cells.

\section{Recycling of Adsorbed B. cereus HSS}

A total of 20 cubes of sponge were added to the optimized medium, inoculated with $2 \mathrm{ml}$ of bacterial suspension, and incubated at $10^{\circ} \mathrm{C}$ for $24 \mathrm{~h}$, followed by removal of the culture medium and addition of a new sterilized medium $(25 \mathrm{ml})$; subsequently, a new cycle was run. This process was regenerated several times. At the end of each cycle, activity of lipase was determined.

\section{Efficiency of B. cereus HSS in Removing Oil and Grease in Addition to Organic Load in Wastewater}

Wastewater samples were collected from the drainage effluent of Misr Petroleum Company, Alexandria, Egypt. A volume of $250 \mathrm{ml}$ of the wastewater sample was introduced into each conical flask, sterilized at $121^{\circ} \mathrm{C}$ for $20 \mathrm{~min}$, and allowed to cool. The sample was inoculated with $B$. cereus HSS containing $10^{6}$ $\mathrm{CFU} / \mathrm{ml}$ and was incubated under shaking conditions at $150 \mathrm{rpm}$. Later, the samples were aseptically drawn every $24 \mathrm{~h}$ for $72 \mathrm{~h}$ and analyzed for oil and grease, total suspended solids (TSS), and biological oxygen demand (BOD) before and after bacterial inoculation. Samples without the bacterial inoculum were kept as control (Bala et al., 2014). The estimation of each parameter was done according to the method described by Clesceri et al. (1999).

The efficiency for organic load reduction was calculated as follows: 


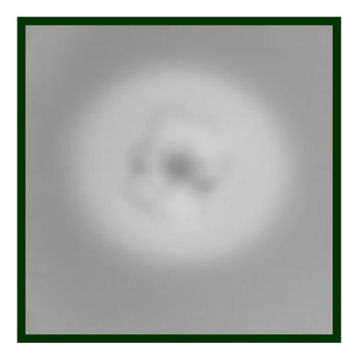

FIGURE 1 | Hydrolytic zone of Tween 80 produced by isolate 3 .

Efficiency \% $(\mathrm{BOD})$ removal $=($ Initial $(\mathrm{BOD})$ of the raw sample -final (BOD) after treatment/ Initial (BOD) of the raw sample) $* 100$

Efficiency \% (TSS) removal $=($ Initial TSS $)$ of the raw sample -final (TSS) after treatment/ Initial (TSS) of the raw sample) $* 100$

Efficiency \% (oil) removal = (Weight of crude oil before treatment (initial) - Weight of crude oil after treatment)/ Weight of crude oil initial)* 100

\section{Analysis of Residual Oil by Gas Chromatography-Mass Spectrometry (GC-MS)}

The residual oil was extracted by dichloromethane. The aqueous phase sample was discarded, and the crude oil containing the solvent was concentrated to approximately $0.1 \mathrm{ml}$ using a rotary evaporator under reduced pressure. The residual oil was subjected to chemical analysis using gas chromatography-mass spectrometry (GC-MS; Agilent Technologies 7890A GC System with a flame ionization detector, a 5975C inert XL MSDTripleAxis Mass Detector and Agilent 19,091S-433 Trace Analysis column). The GC experiments were conducted by injecting $1 \mu \mathrm{L}$ of the sample, operating in the split less mode with an evaporation temperature of $250^{\circ} \mathrm{C}$, pressure of $1.8 \mathrm{bar}$, and flow rate of $2.5 \mathrm{ml} / \mathrm{min}$. Helium carrier gas temperature was maintained in gradients of $50^{\circ} \mathrm{C} / \mathrm{min}, 40^{\circ} \mathrm{C} / \mathrm{min}, 300^{\circ} \mathrm{C} / \mathrm{min}$, and $300^{\circ} \mathrm{C} / 5 \mathrm{~min}$. Compounds were characterized based on the similarities between their mass spectrum and those of the authentic data presented by Wiley Library.

\section{RESULTS AND DISCUSSION}

\section{Qualitative Screening for Extracellular Lipase Production by the Isolated Bacteria}

The capability of all isolates to degrade Tween 80 was tested using Tween agar base medium. Lipase-producing potentiality was investigated based on the size of the clear zone around each colony (Ramle and Abdul Rahim, 2016). Results indicated that all isolates were positive producers of lipase with different efficiency as the lipolytic zone diameter range was $6-20 \mathrm{~mm}$. The highest lipolytic activity was detected for isolate 3 , which recorded $20 \mathrm{~mm}$

TABLE 1 | Screening of lipolytic activities of the isolated bacteria.

\begin{tabular}{lcc}
\hline Isolates & Colony diameter $(\mathbf{m m})$ & Lipolytic zone diameter $(\mathbf{m m})$ \\
\hline 1 & 6 & 12 \\
2 & 5 & 7 \\
3 & 3 & 20 \\
4 & 4 & 9 \\
5 & 4 & 8 \\
6 & 5 & 12 \\
7 & 3 & 13 \\
8 & 3 & 8 \\
9 & 3 & 15 \\
10 & 4 & 17 \\
11 & 4 & 14 \\
12 & 5 & 10 \\
13 & 5 & 10 \\
14 & 4 & 12 \\
15 & 3 & 6 \\
16 & 4 & 6 \\
17 & 4 & 15 \\
18 & 7 & 11 \\
19 & 4 & 6 \\
20 & 3 & 14 \\
\hline
\end{tabular}

(Figure 1) followed by strain $10(17 \mathrm{~mm})$, whereas strains 15,16 , and 19 showed the lowest lipolytic activity $(6 \mathrm{~mm})$ as shown in Table 1. Tween has been used as a substrate in different studies and is recommended as it is more easy and convenient for the detection of lipase activity (Anbu et al., 2011). Lo Giudice et al.

TABLE 2 | Time course production of lipase by the isolated bacteria.

\begin{tabular}{lccc}
\hline Strain number & \multicolumn{2}{c}{ Lipase activity $(\mathbf{U} / \mathbf{m l})$ in different time intervals $(\mathbf{h})$} \\
\cline { 2 - 4 } & $\mathbf{2 4}$ & $\mathbf{4 8}$ & $\mathbf{7 2}$ \\
\hline 1 & 210 & 200 & 50 \\
2 & 75 & 75 & 100 \\
3 & 225 & 105 & 125 \\
4 & 150 & 150 & 75 \\
5 & 125 & 150 & 110 \\
6 & 200 & 175 & 135 \\
7 & 75 & 215 & 220 \\
8 & 125 & 100 & 75 \\
9 & 175 & 125 & 65 \\
10 & 175 & 200 & 200 \\
11 & 100 & 100 & 75 \\
12 & 100 & 100 & 75 \\
13 & 150 & 200 & 210 \\
14 & 200 & 210 & 250 \\
15 & 0 & 75 & 150 \\
16 & 0 & 100 & 50 \\
17 & 100 & 185 & 75 \\
18 & 125 & 125 & 175 \\
19 & 50 & 125 & 150 \\
20 & 170 & 220 & 125
\end{tabular}




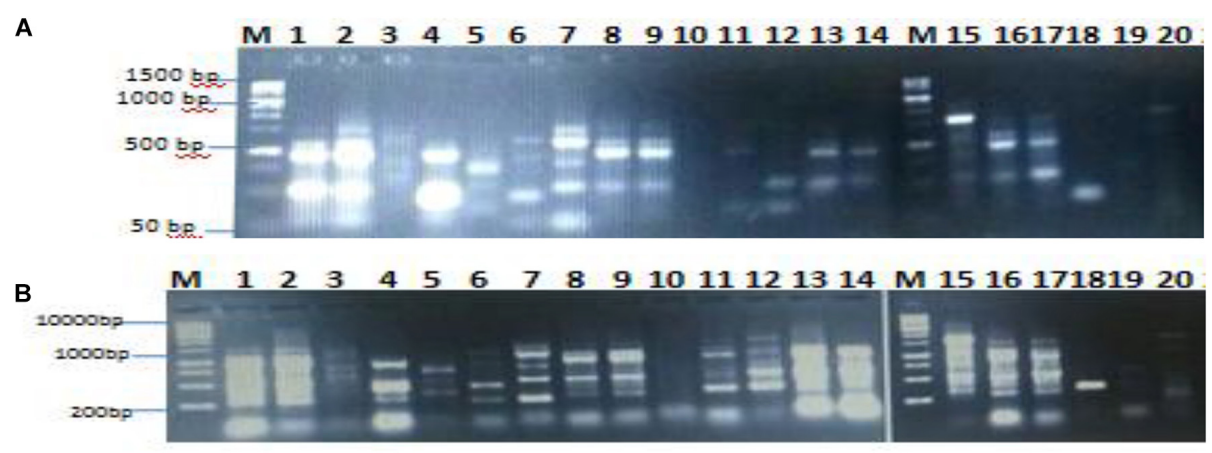

FIGURE 2 | Agarose gel shows polymorphism between isolates using primer 16S F (A) and 16S1100R (B)

(2006) studied the effectiveness of different isolated bacteria for their lipolytic activity on Tween and tributyrin by hydrolytic plate assay, and they reported that among the strains tested for lipid hydrolysis, only 7 isolates were unable to utilize the media, while the remaining hydrolyzed at least one substrate, and the diameters of the halos were generally 9-29 mm using Tween. In a parallel study, Rasmey et al. (2017) reported that among the 56 tested isolates, only 24 isolates were recorded as lipase producers with lipolytic zone diameters of $18-32 \mathrm{~mm}$.

\section{Quantitative Screening of Lipase Production by the Isolated Bacteria}

Secondary screening was carried out on the isolated bacteria to ensure the capability for lipase production in mineral based medium supplemented with $1 \%(\mathrm{v} / \mathrm{v})$ cotton seed oil. Lipase production by the selected isolates was estimated at different time intervals $(24,48$, and $72 \mathrm{~h})$. As shown in Table 2, the highest production of lipase $(225 \mathrm{U} / \mathrm{ml})$ was recorded for strain 3 after $24 \mathrm{~h}$; thus, it was selected for further study. In a parallel study by Rasmey et al. (2017), it was reported that the highest lipase activity $(20.0 \pm 0.29 \mathrm{U} / \mathrm{mL})$ was recorded for Pseudomonas monteilii using olive oil as the substrate in the medium. Similarly, the highest lipase activity $(2.33 \pm 0.12 \mathrm{U})$ was indicated by Staphylococcus sp. in the presence of cotton seed oil as the carbon source (Patel et al., 2018).

\section{Detection of Polymorphism Among Lipase Producers Using RAPD-PCR}

The genetic analysis of the isolated lipase producers was carried out with the main goal of identifying duplications of the same isolates. RAPD-PCR is the most commonly used marker to detect polymorphism and variability (Shahid et al., 2012; Sobhakumari,

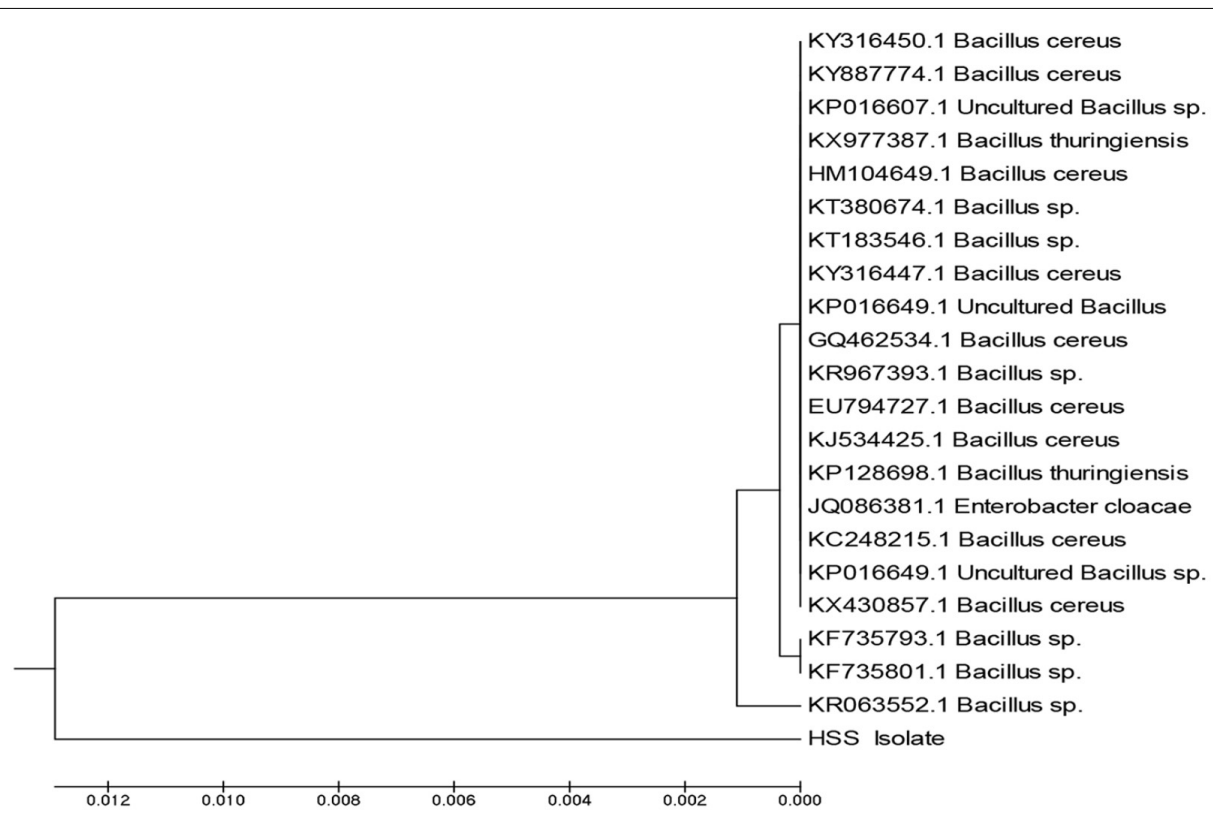

FIGURE 3 | Phylogenetic tree showing the incidental evolutionary relationships between different biological Bacillus species. The dendrogram was generated using the MEGA 5 program. 

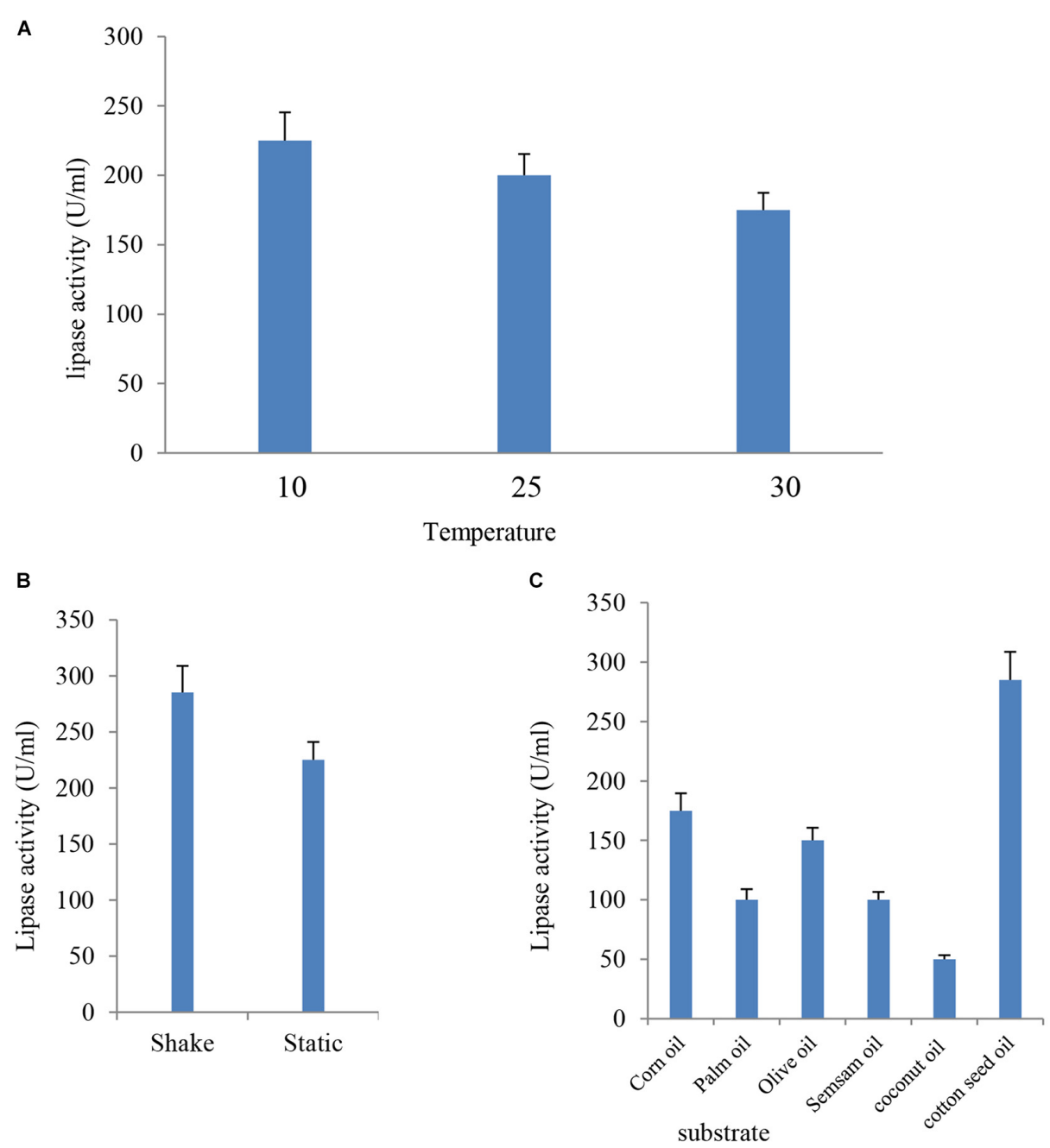

FIGURE 4 | Effect of temperature (A), agitation (B), and different inducer substrates (C) on lipase activity of B. cereus HSS.

2012). It is easy, quick, and requires small quantity of template DNA. In the present study, isolates coded 1-20 were exposed to DNA extraction and RAPD-PCR with the aim to differentiate between the bacterial isolates. As shown in Figures 2A,B, there was clear polymorphism between the isolates, which was identified using different primers namely 16S1100R and 16S F. RAPD-PCR profiling dependent polymorphism was previously used to differentiate between lipase producing bacterial isolates (Tilwari et al., 2016).

\section{Molecular Identification of the Most Promising Isolate}

The comparison of 16S rRNA gene sequence of an isolate with the sequences of the different types of strains provides a powerful tool to classify and identify prokaryotes (Kim and Chun, 2014; Zuppa et al., 2014). In the current study, DNA of isolate 3 was extracted and 16S rRNA gene was amplified; the amplicons produced were analyzed using agarose gel electrophoresis. The sequence was deposited in GenBank and had the accession number MF581790; the isolate was identified as Bacillus cereus HSS with a similarity of $98 \%$. Figure 3 represents the phylogenetic tree showing the incidental evolutionary relationships among different Bacillus species. Bacillus species were previously reported as lipase producers in various studies (Bharathi et al., 2018; Femi-Ola et al., 2018; Sahoo et al., 2018).

\section{Optimization of Fermentation Factors Affect Lipase Production Effect of Temperature on Lipase Production}

The culture media were incubated at different temperatures (10, 25 , and $30^{\circ} \mathrm{C}$ ) under static conditions for the optimum incubation time. Results indicated in Figure $4 \mathbf{A}$ showed that the most suitable temperature for the highest lipase activity $(225 \mathrm{U} / \mathrm{ml})$ was $10^{\circ} \mathrm{C}$, whereas the lowest lipase activity $(175 \mathrm{U} / \mathrm{ml})$ was detected 
TABLE 3 | Levels of examined factors and statistical analysis of the Plackett-Burman experimental design.

\begin{tabular}{|c|c|c|c|c|c|c|c|c|c|c|c|c|}
\hline \multirow[t]{3}{*}{ Trial } & \multicolumn{11}{|c|}{ Factor symbol } & \multirow{3}{*}{$\begin{array}{c}\text { Lipase activity } \\
(\mathrm{U} / \mathrm{ml})\end{array}$} \\
\hline & $\mathrm{S}(\mathrm{g} / \mathrm{l})$ & $\mathbf{Y}$ & $\mathrm{Na}$ & K2 & $\mathbf{M g}$ & $\mathbf{K}$ & $\mathrm{Fe}$ & $\mathrm{pH}$ & CV & IS & 0 & \\
\hline & & & $(g / l)$ & & & & & $\mathrm{pH}$ & $(\mathrm{ml})$ & $(\%)$ & (\%) & \\
\hline 1 & $+[0.8]$ & {$[1.5]$} & $+[0.08]$ & $+[0.03]$ & $+[0.08]$ & $+[0.08]$ & $+[0.002]$ & $+[8]$ & $+[75]$ & $+[2]$ & $+[2]$ & 225 \\
\hline 2 & $-[0.2]$ & $+[1.5]$ & $-[0.03]$ & $+[0.03]$ & $+[0.08]$ & $+[0.08]$ & $-[0.001]$ & $-[6]$ & $-[25]$ & $+[2]$ & $-[0.5]$ & 200 \\
\hline 3 & $-[0.2]$ & $-[0.5]$ & $+[0.08]$ & $-[0.01]$ & $+[0.08]$ & $+[0.08]$ & $+[0.002]$ & $-[6]$ & $-[25]$ & $-[0.5]$ & $+[1]$ & 535 \\
\hline 4 & $+[0.8]$ & $-[0.5]$ & $-[0.03]$ & $+[0.03]$ & $-[0.05]$ & $+[0.08]$ & $+[0.002]$ & $+[8]$ & $-[25]$ & $-[0.5]$ & $-[0.5]$ & 275 \\
\hline 5 & $-[0.2]$ & $+[1.5]$ & $-[0.03]$ & $-[0.01]$ & $+[0.08]$ & $-[0.05]$ & $+[0.002]$ & $+[8]$ & $+[75]$ & $-[0.5]$ & $-[0.5]$ & 150 \\
\hline 6 & $-[0.2]$ & $-[0.5]$ & $+[0.08]$ & $-[0.01]$ & $-0.05]$ & $+[0.08]$ & $-[0.001]$ & $+[8]$ & $+[75]$ & $+[2]$ & $-[0.5]$ & 125 \\
\hline 7 & $-[0.2]$ & $-[0.5]$ & $-[0.03]$ & $+[0.03]$ & $-[0.05]$ & $-[0.05]$ & $+[0.002]$ & $-[6]$ & $+[75]$ & $+[2]$ & $+[2]$ & 250 \\
\hline 8 & $+[0.8]$ & $-[0.5]$ & $-[0.03]$ & $-[0.01]$ & $+[0.08]$ & $-[0.05]$ & $-[0.001]$ & $+[8]$ & $-[25]$ & $+[2]$ & $+[2]$ & 75 \\
\hline 9 & $+[0.8]$ & $+[1.5]$ & $-[0.03]$ & $-[0.01]$ & $-[0.05]$ & $+[0.08]$ & $-[0.001]$ & $-[6]$ & $+[75]$ & $-[0.5]$ & $+[2]$ & 225 \\
\hline 10 & $+[0.8]$ & $+[1.5]$ & $+[0.08]$ & $-[0.01]$ & $-[0.05]$ & $-[0.05]$ & $+[0.002]$ & $-[6]$ & $-[25]$ & $+[2]$ & $-[0.5]$ & 185 \\
\hline 11 & $-[0.2]$ & $+[1.5]$ & $+[0.08]$ & $+[0.03]$ & $-[0.05]$ & $-[0.05]$ & $-[0.001]$ & $+[8]$ & $-[25]$ & $-[0.5]$ & $+[2]$ & 100 \\
\hline 12 & $+[0.8]$ & $-[0.5]$ & $+[.0 .08]$ & $+[0.03]$ & $+[0.08]$ & $-[0.05]$ & $-[0.001]$ & $-[6]$ & $+[75]$ & $-[0.5]$ & $-[0.5]$ & 100 \\
\hline 13 & $0[0.5]$ & $\mathrm{O}[1]$ & O[0] & $\mathrm{O}[0]$ & $0[0.03]$ & O[0] & $\mathrm{O}[0]$ & $0[7]$ & $0[50]$ & $\mathrm{O}[1]$ & $O[1]$ & 285 \\
\hline Main effect & 45.8 & -45.8 & 15.8 & -24 & 20.8 & 120.8 & 88.3 & -49.2 & -54.2 & 62.5 & -90 & \\
\hline$t$-value & 0.629 & -0.629 & 0.213 & -0.327 & 0.281 & 1.895 & 2.16 & -0.677 & -0.749 & -0.749 & -1.32 & \\
\hline
\end{tabular}

S: Sucrose; Y: Yeast extract; $\mathrm{Na}: \mathrm{NaCl} ; \mathrm{K}_{2}: \mathrm{K}_{2} \mathrm{HPO}_{4} ; \mathrm{Mg}: \mathrm{MgSO}_{4} ; \mathrm{K}: \mathrm{KCl} ; \mathrm{Fe}: \mathrm{FeSO}_{4} ; \mathrm{CV}$ : Culture volume; IS: Inoculum size; O: Oil concentration.

at $30^{\circ} \mathrm{C}$. These findings were consistent with previous studies, where lower fermentation temperature had a positive effect on lipase production (Anasontzis et al., 2014) Among the tested range of temperature $\left(15-35^{\circ} \mathrm{C}\right)$, the optimum temperature for cold-active lipase production by Pichia lynferdii NRRL Y-7723 was $20^{\circ} \mathrm{C}$ as previously reported (Park et al., 2013). The effect of temperature on enzyme activity is attributed to its effect on stability, rate of the reaction, substrate solubility as well as direct influence on esterification reaction (Musa et al., 2018).

\section{Effect of Agitation on Lipase Production by B. cereus HSS}

Lipase production was premeditated under the effect of agitation at $10^{\circ} \mathrm{C}$ for $24 \mathrm{~h}$. Data presented in Figure $4 \mathbf{B}$ showed that lipase activity reached a value of $285 \mathrm{U} / \mathrm{ml}$, which represented a 1.3-fold increase at shaking condition when compared with the $(225 \mathrm{U} / \mathrm{ml})$ static condition. Aeration has up-and-down effects on lipase production by different organisms (Gilbert et al., 1991). Enzyme activity had a significant elevation under agitation when compared with the stationary state. Enzyme production increased when the agitation rate increased up to $150 \mathrm{rpm}$, and, subsequently, a reduction in activity was reported (Sooch and Kauldhar, 2013). The decrease in enzyme activity at elevated agitation rates might be attributed to the depletion in the nutrient level and oxygen in the medium and the shared stress on bacterial cells in addition to enzyme structure (Calderbank and MooYoung, 1959).

\section{Effect of Different Inducers on Lipase Production by B. cereus HSS}

Lipases are inducible enzymes. Glycerol, hydrolysable esters, fatty acids, bile salts, Tweens, and triacylglycerols take action as inducers for lipase production (Griebeler et al., 2011). In the present study, sesame oil, corn oil, olive oil, palm oil, coconut oil, and cotton seed oil were tested as inducers for lipase production by $B$. cereus HSS; the enzyme appeared most active toward cotton seed oil with an enzyme activity of $285 \mathrm{U} / \mathrm{ml}$. In contrast, the lipase attacked olive oil, corn oil, palm oil, sesame oil, and coconut oil more slowly (Figure 4C). Cotton seed oil is a cheap, commercial, and available economic source for lipase production. Therefore, it was previously used as a carbon source for lipase production (Abd-Elnaby et al., 2015). The current study indicated that the use of different lipids caused variations in lipase activity. These results are in harmony with the findings of El-Sawah et al. (1995). It was reported in many published experimental data that natural oils stimulate lipase production ( $\mathrm{He}$ and Tan, 2006; Kaushik et al., 2006). Similarly, elevated level of lipase production by Bacillus sp. was observed upon using

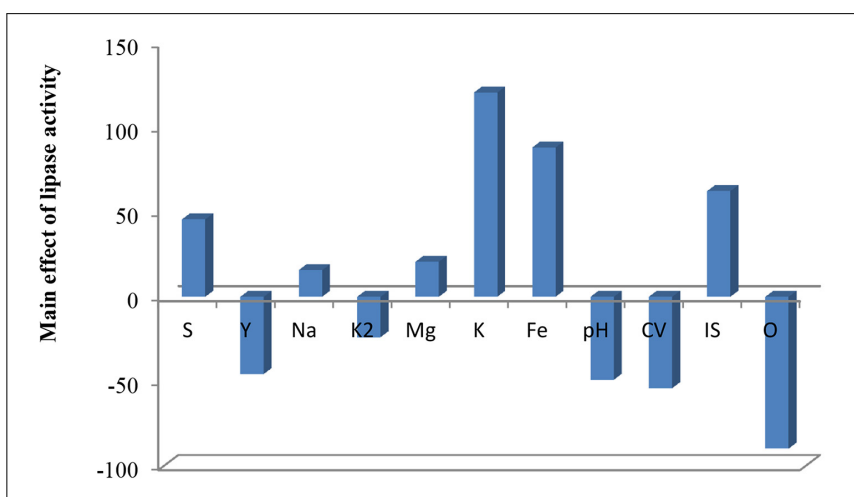

FIGURE 5 | Elucidation of fermentation conditions affecting the production of lipase. 


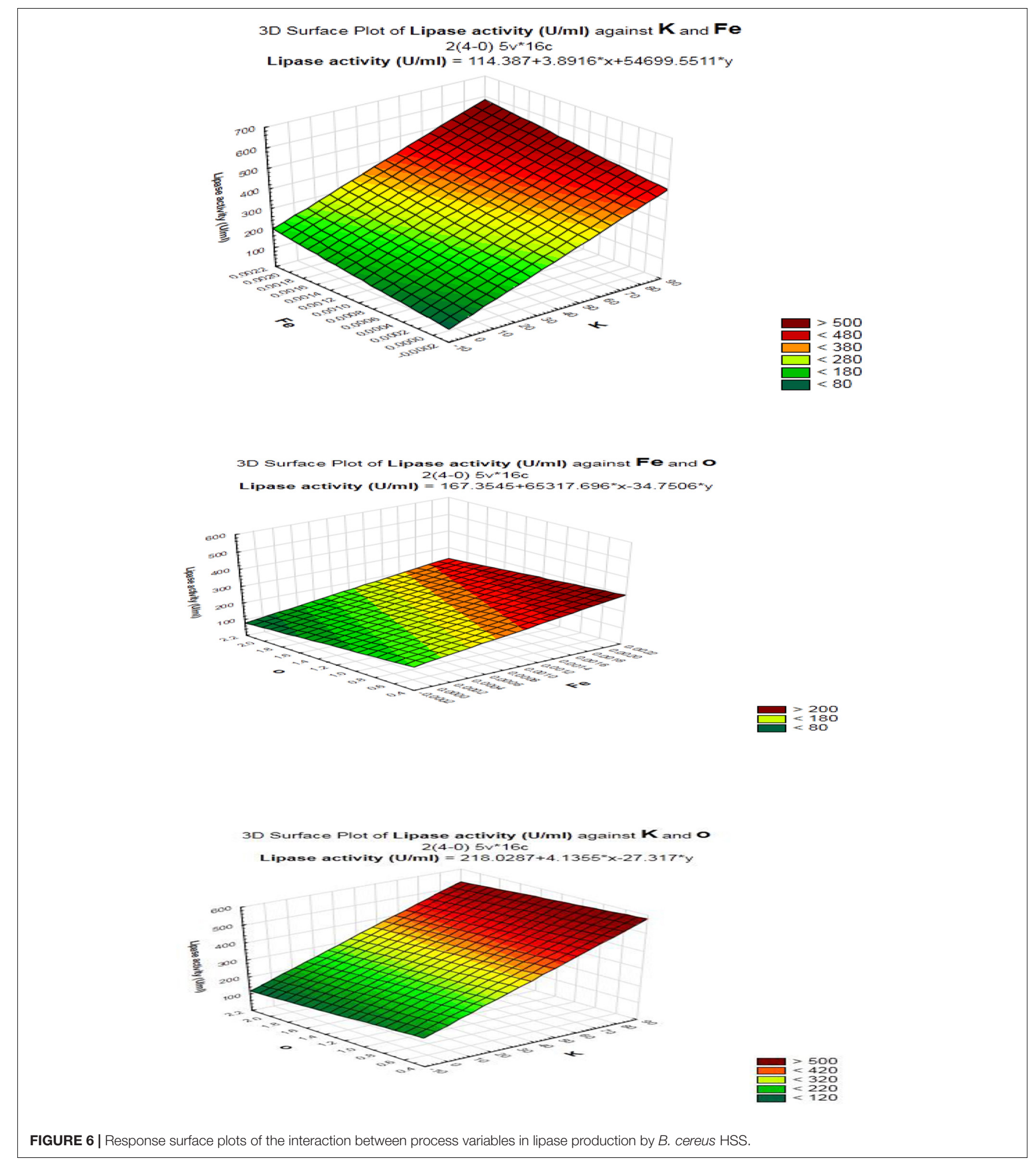

olive oil as substrate in the custom medium (Eltaweel et al., 2005).

El-Sawah et al. (1995) tested the effect of different substrates that included olein, sunflower, coconut, olive oil, soybean, cotton seed, stearin, butter, castor, and tallow fat, which were appended to the basal medium at a concentration of $1 \%$. It was shown that olive oil was the most favorable substrate for the increased production of lipase by Lactobacillus delbrueckii subsp. bulgaricus. 


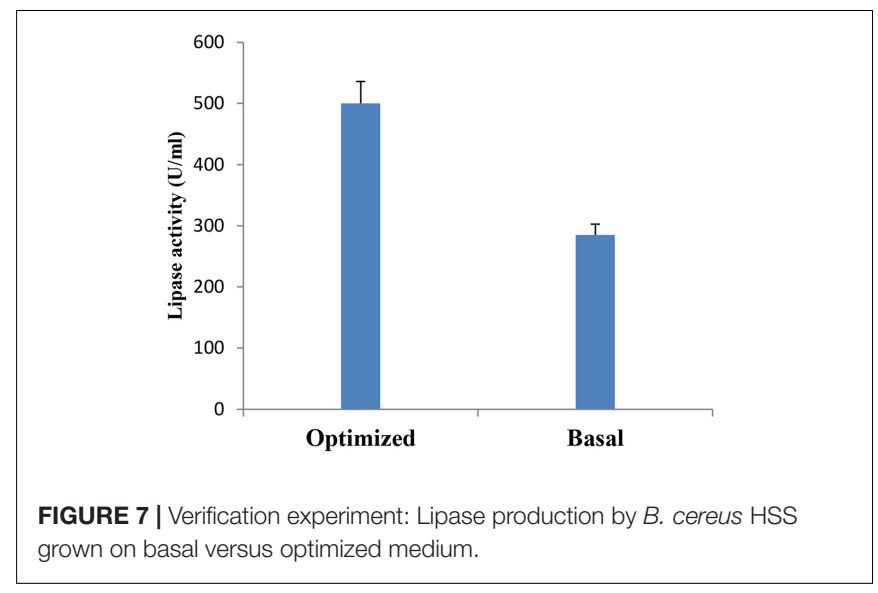

Divya et al. (2015) studied lipase production by coldadapted Geotrichum sp. and Rhodotorula sp. with a wide range of commercial oils like sunflower oil, olive oil, coconut oil, vanaspati, and ghee at $30^{\circ} \mathrm{C}$ and reported that palm oil was the most preferable substrate for maximum lipase production.

\section{Optimization of Culture Conditions Using Plackett-Burman Experimental Design}

Plackett-Burman experimental design was used with 11 different fermentation conditions. The examined factors and their levels are presented in Table 3 . The average results of duplicate experiments are given as the response $(\mathrm{U} / \mathrm{ml})$ (Table 3). The estimated main effect of each variable on lipase production and $t$-values were shown in Table 3 and Figure 5.

As shown (Figure 5), positive effects of sucrose, $\mathrm{NaCl}$, $\mathrm{MgSO}_{4}, \mathrm{KCL}, \mathrm{FeSO}_{4}$, and inoculum size on lipase production were observed, which means that high levels of these parameters will correspond to higher lipase activity, whereas yeast extract, $\mathrm{K}_{2} \mathrm{HPO}_{4}, \mathrm{pH}$, culture volume, oil concentration had negative effects. Thus, the predicted optimum medium

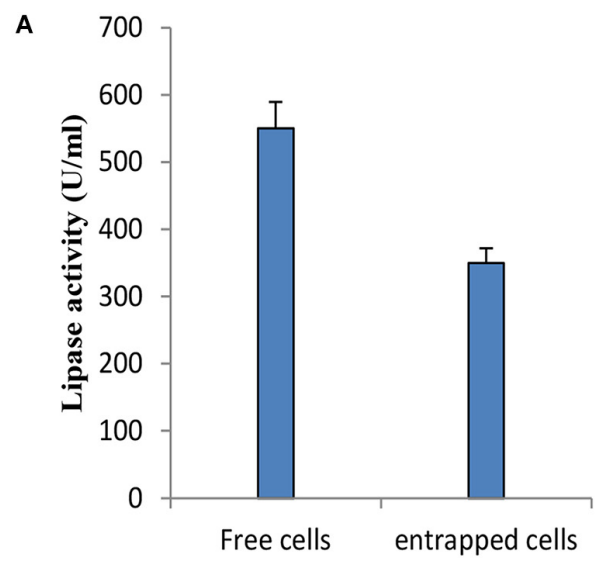

C
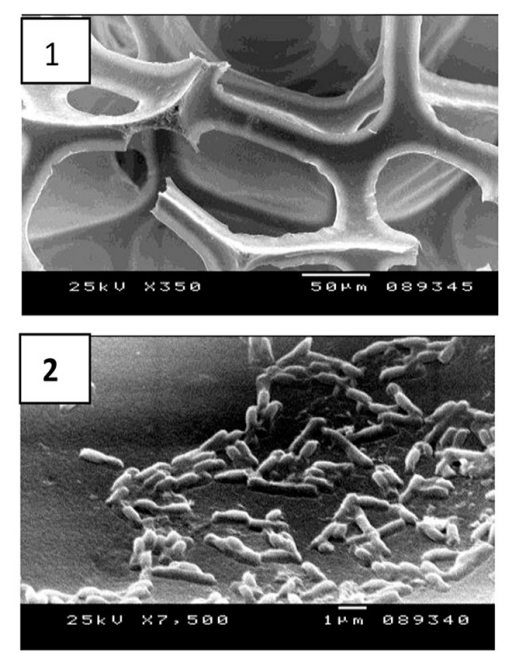

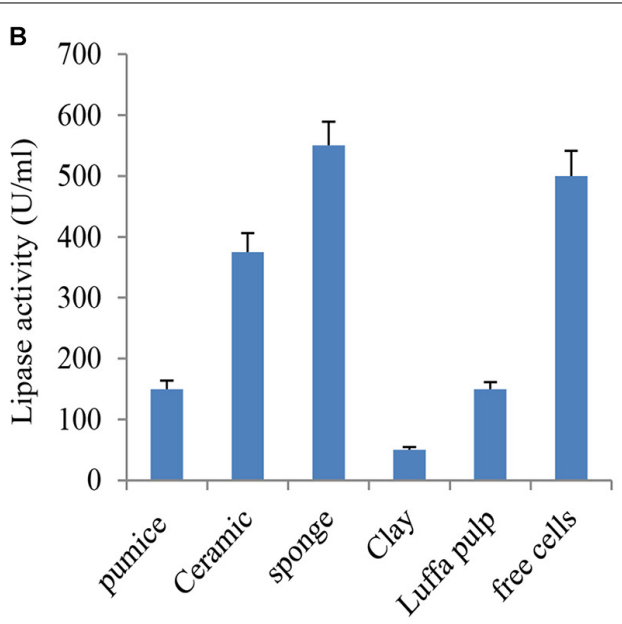

Solid supports

D

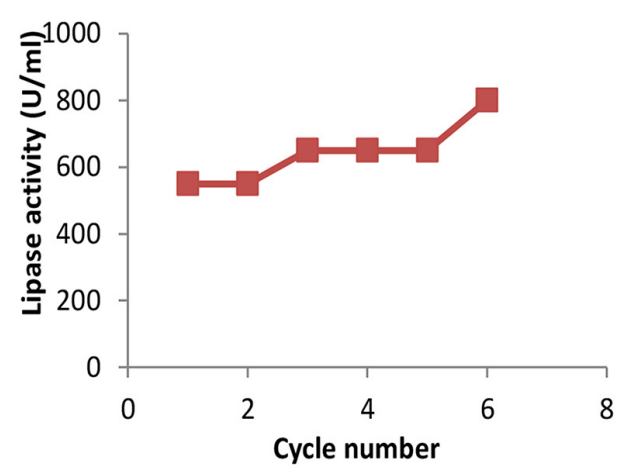

FIGURE 8 | Production of lipase by entrapped cells (A) and adsorbed cells on different support materials (B), electron micrograph of sponge (C1) and cells adsorbed on sponge (C2), and recycling of adsorbed B. cereus HSS on sponge (D). 
TABLE 4 | Removal efficiency percentages of BOD, TSS, and oil and grease after treatment by the lipase producer marine $B$. cereus HSS.

\begin{tabular}{lccc}
\hline $\begin{array}{l}\text { Incubation } \\
\text { time (h) }\end{array}$ & $\begin{array}{c}\text { Removal } \\
\text { efficiency (\%) } \\
\text { of BOD }\end{array}$ & $\begin{array}{c}\text { Removal } \\
\text { efficiency (\%) } \\
\text { of TSS }\end{array}$ & $\begin{array}{c}\text { Degradation } \\
\text { efficiency (\%) } \\
\text { of oil\& grease }\end{array}$ \\
\hline 24 & 10 & 60 & 15 \\
48 & 22 & 87.2 & 40 \\
72 & 87.63 & 90 & 94.7 \\
\hline
\end{tabular}

that resulted from this experiment included the following (g/l) sucrose, 0.8; yeast extract, $0.2 ; \mathrm{K}_{2} \mathrm{HPO}_{4}, 0.01 ; \mathrm{MgSO}_{4}$, 0.08 ; and $\mathrm{KCl}, 0.08 ; \mathrm{pH}, 6$; culture volume, 25; oil concentration, $0.5 \%$. Data analysis using $t$-test (Table 3 ) revealed that $\mathrm{FeSO}_{4}, \mathrm{KCl}$, and oil concentrations were the most significant factors that affected lipase activity. Interactions among the three factors are illustrated (Figure 6). Many authors applied Plackett-Burman experimental design for the enhancement of enzyme production (Collaa et al., 2016; Kai and Peisheng, 2016; Vasiee et al., 2016; Ebrahimipour et al., 2017; Mazhar et al., 2017).

A verification test was carried out to validate the results gained from the statistical analysis of Plackett-Burman design, using the predicted optimized media against the basal condition media. As shown in Figure 7, lipase activity reached a value of $500 \mathrm{U} / \mathrm{ml}$ with an 1.8 -fold increase when grown in the optimized medium compared with the basal condition. In comparable studies conducted by Kai and Peisheng (2016) and Sharma et al. (2009), 1.85 and 1.6 fold increases, respectively, were achieved in lipase production upon the application of the
Plackett-Burman experimental design for medium optimization.

Another study by Maharana and Ray (2014) showed that the formulated medium predicted by the Plackett-Burman design enhanced lipase production by Pseudomonas sp. Akm-L5 at $15^{\circ} \mathrm{C}$ by 3.2 -fold.

\section{Effect of Immobilization on Lipase Production by $B$. cereus HSS}

Immobilization of microbial cells could eliminate the time consuming, tedious, and costly steps involved in the isolation and purification of intracellular enzymes. It also intends to improve the stability of the enzyme (Chandorkar et al., 2014; Lee et al., 2017). To study the effect of entrapment on lipase activity, entrapment of $B$. cereus HSS cells was carried out in 3\% sodium alginate. Results (Figure 8A) showed that entrapped cells exhibited lower lipase activity when compared with free cells. Adsorption of cells was carried out using luffa pulp, pumice, clay, ceramic, and sponge as support materials. The adsorbed cells were tested for their potentiality in the production of lipase. As shown in Figure 8B, lipase activity was decreased by 1.5, 3.3, 11 and 3.7 fold upon using ceramic, pumice, clay, and luffa, respectively. The productivity obtained by the immobilized cells on sponge was considerably higher than the free cells. A comparative study indicated that the dramatic variation and the efficiency of an immobilization process rely on the support used (Musa et al., 2018). Thus, cells adsorbed on sponge (Figure 8C) were chosen to complete the study, when these immobilized cells were reused for five successive cycles.

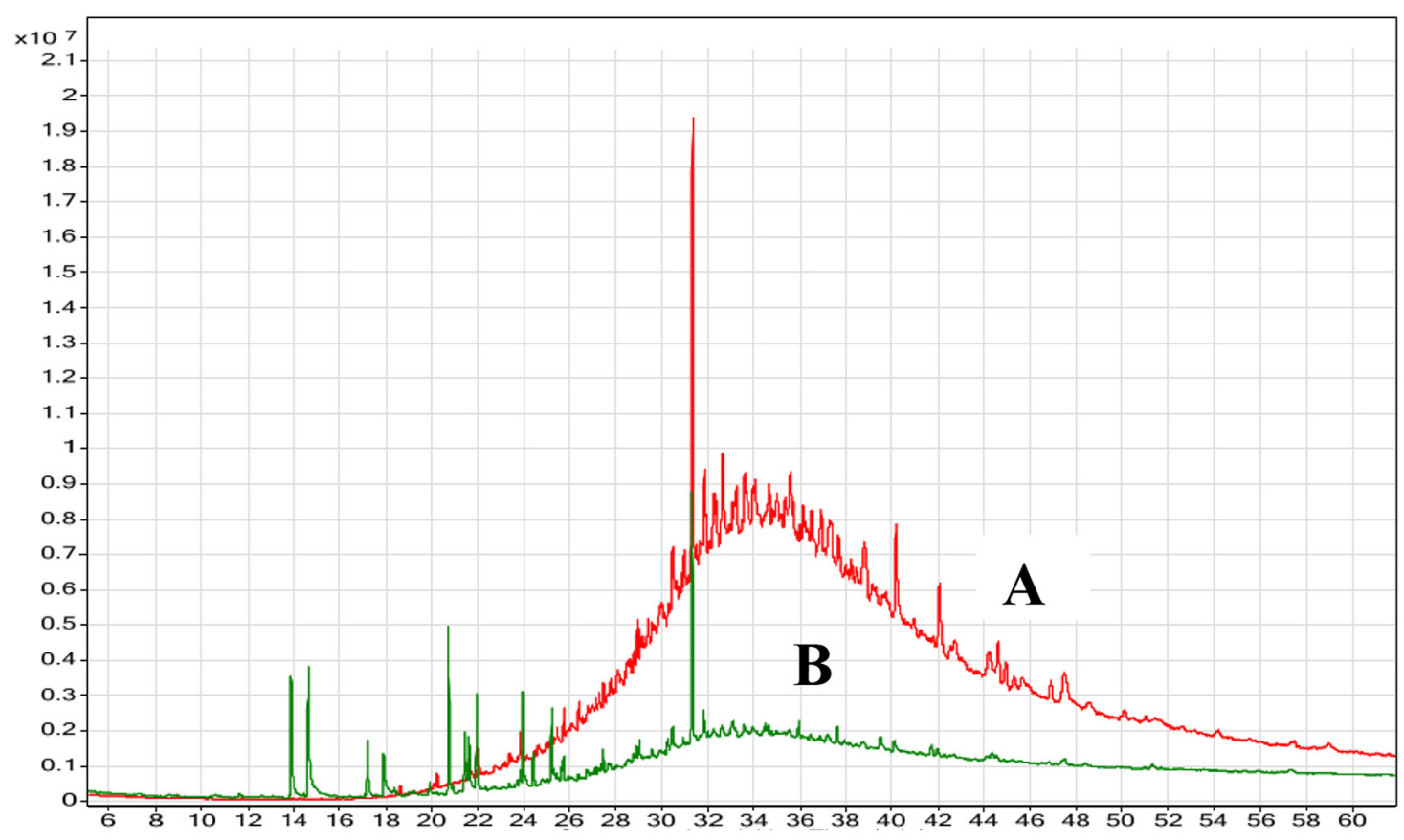

FIGURE 9 | GC-MS chromatogram of the oily wastewater (A) control (untreated) and (B) treated with lipase producer B. cereus HSS after 72 h. 
As shown in Figure 8D, lipase activity increased in the first cycle and was found to be nearly constant from the second to the fourth cycles, followed by an increase in the fifth cycle to reach a value of $800 \mathrm{U} / \mathrm{ml}$. Accordingly, recycling of $B$. cereus HSS cells on sponge revealed increases of 1.5 -fold and 2.8 -fold when compared with free cells grown in the optimized and basal conditions, respectively.

It was reported that in comparison with free suspended cells, immobilized cells exhibit tolerance to toxic substrates, enhance fermentation productivity, can adapt to a wide range of $\mathrm{pH}$ environments and high process temperature, and are reusable (Jaiswal and Joseph, 2011).

\section{Efficiency of $B$. cereus HSS in Wastewater Treatment}

The present experiment was a trial for the reduction of contaminants in wastewater by the marine lipase producer B. cereus HSS. To achieve this goal, BOD, TSS, and oil and grease were estimated before and after the treatment of wastewater with $B$. cereus HSS. Results mentioned in Table 4 showed that the highest reduction efficiencies of BOD, TSS, and oil and grease were 87.63, 90, and $94.7 \%$, respectively, after $72 \mathrm{~h}$. These results confirmed the reduction efficiency of the tested parameters at low temperature, which is considered to be feasible and economic, representing a low energy biological method compared with the traditional methods that require high temperature and energy levels. In a similar study, El Bestawy et al. (2005) confirmed the efficiency of biological treatment of wastewater using the lipase producer Pseudomonas spp. individually or in combination. The same finding was also reported in another study (Bala et al., 2014).

\section{GC-MS Analysis of the Residual Oil}

The degradation of oily wastes by marine $B$. cereus HSS after $72 \mathrm{~h}$ of incubation was confirmed using GC-MS analysis and was

\section{REFERENCES}

Abd-Elnaby, H., Beltagy, E. A., Abo-Elela, G. M., and El-Sersy, N. A. (2015). Achromobacter sp. and Virgibacillus pantothenticus as models of thermotolerant lipase-producing marine bacteria from North Delta sediments (Egypt). Afr. J. Microbiol. Res. 9, 1001-1011. doi: 10.5897/AJMR2014.6828

Anasontzis, G. E., Pena, M. S., Spadiut, O., Brumer, H., and Olsson, L. (2014). Effects of temperature and glycerol and methanol-feeding profiles on the production of recombinant galactose oxidase in Pichia pastoris. Biotechnol. Prog. 30, 728-735. doi: 10.1002/btpr.1878

Anbu, P., Noh, M., Kim, D., Seo, J., Hur, B., and Min, K. H. (2011). Screening and optimization of extracellular lipases by Acinetobacter species isolated from oil-contaminated soil in South Korea. Afr. J. Biotechnol. 10, 4147-4156.

Awad, G., Mostafa, H., Danial, E. N., Abdelwahed, N. A., and Awad, H. M. (2015). Enhanced production of thermostable lipase from Bacillus cereus ASSCRC-P1 in waste frying oil based medium using statistical experimental design. J. Appl. Pharm. Sci. 5, 7-15. doi: 10.7324/JAPS.2015.50902

Bala, J. D., Lalung, J., and Ismail, N. (2014). Biodegradation of palm oil mill effluent (POME) by bacteria. Int. J. Sci. Res. 4, 1-10.

Betigeri, S. S., and Neau, S. H. (2002). Immobilization of lipase using hydrophilic polymers in the form of hydrogel beads. Biomaterials 23, 3627-3636. doi: 10 . 1016/S0142-9612(02)00095-9

Bharathi, D., Rajalakshmi, G., and Komathi, S. (2018). Optimization and production of lipase enzyme from bacterial strains isolated from petrol spilled soil. J. King Saud Univ. Sci. 1-4. compared with the control (untreated waste). Chromatographic profile of the extracted oil (Figure 9) showed a remarkable decrease in the concentration of fatty acids $\left(n-\mathrm{Cl}_{2}-n-\mathrm{C}_{23}\right)$. On the other hand, complete removal of other compounds $\left(\mathrm{n}-\mathrm{C}_{25}-\mathrm{n}-\mathrm{C}_{32}\right)$ was detected after $72 \mathrm{~h}$. Shon et al. (2002) confirmed the removal efficiency of fat, oil, and grease by Pseudomonas sp. strain D2D3. Another study found that the biological addition of microorganisms to wastes showed efficiency in removing fat, oil, and grease from wastewater (Kang, 1988).

\section{CONCLUSION}

The current research explored our local environments, searching for marine bacterial isolates that produce lipase. It suggested that $B$. cereus HSS isolated from the local marine habitat had the potentiality for lipase production. Optimization of the fermentation conditions and the medium components was carried out using one factor at a time experiment, PlackettBurman experimental design and immobilization, indicating a 2.8 -fold increase in lipase activity. The marine isolate B. cereus HSS would be potentially useful for the removal of grease traps to treat oily wastewaters, which would represent an economic alternative for wastewater treatment. Large scale applications in waste treatment need to be conducted in the future work.

\section{AUTHOR CONTRIBUTIONS}

SH conceived, designed, and coordinated the study. SH, HAEL, and SA carried out the experiments. All authors read and approved the final manuscript.

Cai-hong, W., Run-fang, G., Hong-wei, Y., and Ying-min, J. (2008). Cloning and sequence analysis of a novel cold-adapted lipase gene from strain lip35 (Pseudomonas sp.). Agric. Sci. China 7, 1216-1221. doi: 10.1016/S1671-2927(08) 60167-4

Calderbank, P. H., and Moo-Young, M. B. (1959). The prediction of power consumption in the agitation of non-newtonian fluids. Trans. Inst. Chem. Eng. 37, 26-33. doi: 10.1016/j.cherd.2017.01.018

Cavicchioli, R., Charlton, T., Ertan, H., Mohd Omar, S., Siddiqui, K. S., and Williams, T. J. (2011). Biotechnological uses of enzymes from psychrophiles. Microb. Biotechnol. 4, 449-460. doi: 10.1111/j.1751-7915.2011.00258.x

Chandorkar, V., Gomashe, A. V., and Parlewar, S. (2014). Production of lipase by immobilized cells of Aspergillus niger. Int. J. Curr. Microbiol. Appl. Sci. 3, 703-707. doi: 10.1016/S0032-9592(01)00340-5

Chary, P., and Devi, Y. (2018). Lipases and their applications-An applied research in West Asia. Asian J. Biotechnol. Bioresour. Technol. 3, 1-11. doi: 10.9734/ AJB2T/2018/38852

Clesceri, L. S., Greenberg, C. G., and Eaton, A. D. (1999). Standard Method for the Examination of Water and Wastewater, 20th Edn. Washington, DC: American Public Health Association, 235-237.

Collaa, L. M., Primaz, A. L., Benedetti, S., Loss, R. A., de Limaa, M., Reinehr, C. O., et al. (2016). Surface response methodology for the optimization of lipase production under submerged fermentation by filamentous fungi. Braz. J. Microbiol. 47, 461-467. doi: 10.1016/j.bjm.2016.01.028

Divya, K., Naga, P., and Padma, N. (2015). Psychrophilic yeast isolates for coldactive lipase production. Int. J. Sci. Prog. Res. 10, 93-97. 
Ebrahimipour, G., Sadeghi, H., and Zarinviarsag, M. (2017). Statistical methodologies for the optimization of lipase and biosurfactant by Ochrobactrum intermedium strain MZV101 in an identical medium for detergent applications molecules. Molecules 22, 2-15. doi: 10.3390/molecules22091460

Eikmeier, H., and Rhem, H. J. (1987). Stability of calcium alginate during citric acid production by immobilized Aspergillus niger. Appl. Microbiol. Biotechnol. 26, 105-111. doi: 10.1016/j.sjbs.2012.01.004

El Bestawy, E., Mohamed El-Masry, H., and El-Ad, E. (2005). The potentiality of free Gram-negative bacteria for removing oil and grease from contaminated industrial effluents. World J. Microbiol. Biotechnol. 21, 815-822. doi: 10.1007/ s11274-004-2239-8

El-Sawah, M. M. A., Sherief, A. A., and Bayoumy, S. M. (1995). Enzymatic properties of lipase and characteristics production by Lactobacillus delbrueckii subsp, bulgaricus. Antonie Van Leeuwenhoek 67, 357-362. doi: 10.1007/BF0087 2935

Eltaweel, M. A., Rahman, R. N. Z. R. A., Salleh, A. B., and Basri, M. (2005). An organic solvent-stable lipase from Bacillus sp. strain 42. Ann. Microbiol. 55, 187-192.

Ephraim, D. P., Bhat, S. G., and Muthuswam, C. K. (2014). Lipase production by immobilized marine Bacillus smithii BTMS11 and its potential application in wastewater treatment. Int. J. Curr. Biotechnol. 2, 1-8.

Femi-Ola, T. O., Odeyemi, A. T., Olaiya, B. S., and Ojo, O. O. (2018). Characterization of lipase from Bacillus subtilis Isolated from oil contaminated soil. J. Appl. Environ. Microbiol. 6, 10-17. doi: 10.12691/jaem-6-1-2

Gabrielczyk, J., Duensing, T., Buchholz, S., Schwinges, A., and Jördening, H. J. (2018). A Comparative study on immobilization of fructosyltransferase in biodegradable polymers by electrospinning. J. Appl. Environ. Microbiol. 185, 847-862. doi: 10.1007/s12010-018-2694-6

Gilbert, E. T. L., Bert, E. J., Cornish, A., and Jone, C. W. (1991). Purification and properties of extracellular lipase from Pseudomonas aeruginosa EF2. J. Gen. Microbiol. 137, 2223-2229. doi: 10.1099/00221287-137-9-2223

Griebeler, N., Polloni, A., Remonatto, D., Arbter, F., Vardanega, R., Cechet, J., et al. (2011). Isolation and screening of lipase-producing fungi with hydrolytic activity. Food Bioprocess Technol. 4, 578-586. doi: 10.1016/j.enzmictec.2010. 12.004

Hasan, F., Shah, A. A., and Hameed, A. (2006). Industrial applications of microbial lipases. Enzyme Microb. Technol. 2, 235-251. doi: 10.1016/j.enzmictec.2005. 10.016

He, Y.-Q., and Tan, T. W. (2006). Use of response surface methodology to optimize culture medium for production of lipase with Candida sp. J. Mol. Catal. B Enzym. 43, 99-125. doi: 10.1016/j.molcatb.2006.02.018

Hu, J., Cai, W., Wang, C., Du, Z., Lin, J., and Cai, J. (2018). Purification and characterization of alkaline lipase production by Pseudomonas aeruginosa HFE733 and application for biodegradation in food wastewater treatment. Biotechnol. Biotechnol. Equip. 32, 583-590. doi: 10.1080/13102818.2018.1446764

Jaiswal, N., and Joseph, B. (2011). Production of extracellular cold active lipase by Curtobacterium sp. using cell immobilization. Int. J. Genet. Eng. Biotechnol. 2, 33-46.

Jensen, R. G. (1983). Detection and determination of lipase (acylglycerol hydrolase) activity from various sources. Lipids 18, 650-657. doi: 10.1007/BF02534677

Joshi, G. K., Kumar, S., Tripathi, B. N., and Sharma, V. (2006). Production of alkaline lipase by Corynebacterium paurometabolum, MTCC 6841 isolated from lake Naukuchiatal, Uttaranchal State, India. Curr. Microbiol. 52, 354-358. doi: 10.1007/s00284-005-0224-6

Kai, W., and Peisheng, Y. (2016). Optimization of lipase production from a novel strain Thalassospira permensis M35-15 using response surface methodology. Bioengineered 7, 298-303. doi: 10.1080/21655979.2016.1197713

Kang, S. (1988). Hydrolysis of Olive Oil by Immobilized Lipase from Candida rugosa in Reverse Phase System. Ph.D. Thesis, Korea Advanced Institute of Science and Technology, Korea, 8-37.

Kanwar, S. S., Gupta, M., Gupta, R., Kaushal, R. K., and Chimni, S. (2006). Properties of hydrogel-entrapped lipase of thermophilic Pseudomonas aeruginosa BTS2. Ind. J. Biotechnol. 5, 292-297.

Kaushik, R., Saran, S., Isar, J., and Saxena, R. K. (2006). Statistical optimization of medium components and growth conditions by response surface methodology to enhance lipase production by Aspergillus carneus. J. Mol. Catal. B Enzym. 40, 121-126. doi: 10.1016/j.molcatb.2006.02.019
Kim, M., and Chun, J. (2014). 16S rRNA gene-based identification of bacteria and Archaea using the 741Ez Taxon server. Methods Microbiol. 41, 61-74. doi: 10.1016/bs.mim.2014.08.001

Kirby, L. (1993). DNA Fingerprinting: An Introduction. New York, NY: Oxford University Press.

Lajis, A. F. B. (2018). Realm of thermoalkaline lipases in bioprocess commodities Lajis. Hindawi J. Lipids 2018, 1-22. doi: 10.1155/2018/5659683

Lee, C. W., Jang, S., and Chung, H. (2017). Improving the stability of cold-adapted enzymes by immobilization. Catalysts 7:112. doi: 10.3390/catal7040112

Lindsay, D., Brozel, V. S., Mostert, J. F., and von Holy, A. (2000). Physiology of dairy associated Bacillus sp. over a wide $\mathrm{pH}$ range. Int. J. Food Microbiol. 54, 49-62. doi: 10.1016/S0168-1605(99)00178-6

Lo Giudice, A., Michaud, L., de Pascale, D., De Domenico, M., di Prisco, G., Fani, R., et al. (2006). Lipolytic activity of Antarctic cold-adapted marine bacteria (Terra Nova Bay, Ross Sea). J. Appl. Microbiol. 101, 1039-1048. doi: $10.1111 /$ j.1365-2672.2006.03006.x

Maharana, A. K., and Ray, P. (2014). Application of Plackett-Burman design for improved cold temperature production of lipase by psychrotolerant Pseudomonas sp. AKM-L5. Int. J. Curr. Microbiol. Appl. Sci. 3, 269-282. doi: 10.1016/j.molcatb.2015.07.005

Margesin, R., and Feller, G. (2010). Biotechnological applications of psychrophiles. Environ. Technol. 31, 835-844. doi: 10.1080/09593331003663328

Mazhar, H., Abbas, N., Ali, S., Sohail, A., Hussain, Z., and Ali, S. S. (2017). Optimized production of lipase from Bacillus subtilis PCSIRNL-39 A. Afr. J. Biotechnol. 16, 1106-1115. doi: 10.5897/AJB2017.15924

Musa, N., Latip, W., Abd Rahman, R. N., Salleh, A., and Ali, M. S. (2018). Immobilization of an Antarctic Pseudomonas AMS8 lipase for low temperature ethyl hexanoate synthesis. Catalysts 8:234. doi: 10.3390/catal8060234

Park, S., Kim, J., Bae, J., Hou, C., and Kim, H. (2013). Optimization of culture conditions for production of a novel cold-active lipase from Pichia lynferdii NRRL Y-7723. J. Agric. Food Chem. 61, 882-886. doi: 10.1021/jf304919y

Patel, P., and Desai, P. (2018). Isolation, identification and production of lipase producing bacteria from oil contaminated soil. BMR Microbiol. 4, 1-7.

Patel, U., Chandpura, J., Chauhan, K., and Gupte, S. (2018). Screening and isolation of an organic solvent tolerant lipase producing bacteria from various oil contaminated sites. Indian J. Appl. Microbiol. 21, 22-36.

Plackett, R. L., and Burman, J. P. (1946). The design of optimum multifactorial experiments. Biometrica 33, 305-325. doi: 10.1093/biomet/33.4.305

Ramle, Z., and Abdul Rahim, R. (2016). Psychrophilic lipase from Arctic bacterium. Trop. Life Sci. Res. 27, 151-157. doi: 10.21315/tlsr2016.27.3.21

Rasmey, A., Akram, A. A., Gaber, S., and Mahran, F. (2017). Characterization and optimization of lipase activity produced by Pseudomonas monteilii 2403KY120354 isolated from ground beef. Afr. J. Biotechnol. 16, 96-105. doi: 10. 5897/AJB2016.15820

Sahoo, R. K., Kumar, M., Mohanty, S., Sawyer, M., Rahman, P. K. S. M., Sukla, L. B., et al. (2018). Statistical optimization for lipase production from solid waste of vegetable oil industry. Prep. Biochem. Biotechnol. 48, 321-326. doi: $10.1080 / 10826068.2018 .1431785$

Salihu, A., and Alam, M. Z. (2012). Production and applications of microbial lipases: a review. Sci. Res. Essays 7, 2667-2677.

Sambrook, J., Fritsch, E. F., and Maniatis, T. (1989). Molecular Cloning. A Laboratory Manul. Cold Spring Harbor, NY: Cold Spring Harbor Laboratory Press.

Sarac, N., and Ugur, A. (2015). A green alternative for oily wastewater treatment: lipase from Acinetobacter haemolyticus NS02-30. Desalination. Water Treat. 57, 1-10. doi: 10.1080/09593330.2018.1454512

Sarmah, N., Revathi, D., Sheelu, G., Yamuna Rani, K., Sridhar, S., Mehtab, V., et al. (2018). Recent advances on sources and industrial applications of lipases. Biotechnol. Prog. 34, 5-28. doi: 10.1002/btpr.2581

Saxena, R. K., Sheoran, A., Giri, B., and Davidson, W. S. (2003). Purification strategies for microbial lipases. J. Microbiol. Methods 52, 1-18. doi: 10.1016/S01677012(02)00161-6

Shahid, M. T. H., Khan, F. A., Saeed, A., Aslam, M., and Rasul, F. (2012). Development of somaclones in sugarcane genotype BF-162 and assessment of variability by random amplified polymorphic DNA (RAPD) and simple sequence repeats (SSR) markers in selected red rot resistant somaclones. Afr. J. Biotechnol. 11, 3502-3513. doi: 10.1080/14620316.2014.11513041 
Sharma, A., Bardhan, D., and Patel, R. (2009). Optimization of physical parameters for lipase production from Arthrobacter sp. BGCC\#490. Indian J. Biochem. Biophys. 46, 178-183.

Shon, K. H., Tian, D., Kwon, D.-Y., Jin, C.-S., and Lee, T.-J. (2002). Degradation of fat, oil, and grease (FOGs) by lipase-producing bacterium Pseudomonas sp. Strain D2D3. J. Microbiol. Biotechnol. 12, 583-591.

Silva-Bedoya, L. M., Sánchez-Pinzón, M. S., Cadavid-Restrepo, G. E., and MorenoHerrera, C. X. (2016). Bacterial community analysis of an industrial wastewater treatment plant in Colombia with screening for lipid-degrading microorganisms. Microbiol. Res. 192, 313-325. doi: 10.1016/j.micres.2016.08.006

Sobhakumari, V. P. (2012). Assessment of somaclonal variation in sugarcane. Afr. J. Biotechnol. 87, 15303-15309. doi: 10.1007/s11627-014-9660-y

Sooch, B., and Kauldhar, B. (2013). Influence of multiple bioprocess parameters on production of lipase from Pseudomonas sp. BWS-5. Braz. Arch. Biol. Technol. 56, 711-721. doi: 10.1590/S1516-89132013000500002

Tilwari, A., Nety, A., and Singh, R. (2016). RAPD PCR profiling of lipase producing bacterial isolates from Anhoni hot spring, central India. J. Bioeng. Biomed. Sci. 6:27. doi: 10.4172/2155-9538.C1.008

Treichel, H., Oliveira, D. D., Mazuti, M. A., Luccio, M. D., and Oliveira, J. V. (2010). A review on microbial lipases production. Food Bioproc. Technol. 3, 182-196. doi: 10.1007/s11947-009-0202-2

Vakhlu, J., and Kour, A. (2006). Yeast lipases: enzyme purification, biochemical properties and gene cloning. Electron. J. Biotechnol. 9, 69-85. doi: 10.2225/vol9issue 1-fulltext-9
Vasiee, A., Behbahani, B. A., Yazdi, F. T., and Moradi, S. (2016). Optimization of the production conditions of the lipase produced by Bacillus cereus from rice flour through Plackett-Burman Design (PBD) and response surface methodology (RSM). Microb. Pathog. 101, 36-43. doi: 10.1016/j.micpath.2016. 10.020

Yu, Y., Li, H., Zeng, Y., and Chen, B. (2009). Extracellular enzymes of coldadapted bacteria from Arctic sea ice. Canada basin. Polar Biol. 32, 1539-1547. doi: 10.1007/s00300-009-0654-x

Zuppa, A., Costantini, S., and Costantini, M. (2014). Comparative sequence analysis of bacterial 743 symbionts from the marine sponges Geodia cydonium and Ircinia muscarum. Bioinformation 10, 196-200. doi: 10.6026/ 97320630010196

Conflict of Interest Statement: The authors declare that the research was conducted in the absence of any commercial or financial relationships that could be construed as a potential conflict of interest.

Copyright (C) 2018 Hassan, Abd El Latif and Ali. This is an open-access article distributed under the terms of the Creative Commons Attribution License (CC BY). The use, distribution or reproduction in other forums is permitted, provided the original author(s) and the copyright owner(s) are credited and that the original publication in this journal is cited, in accordance with accepted academic practice. No use, distribution or reproduction is permitted which does not comply with these terms. 